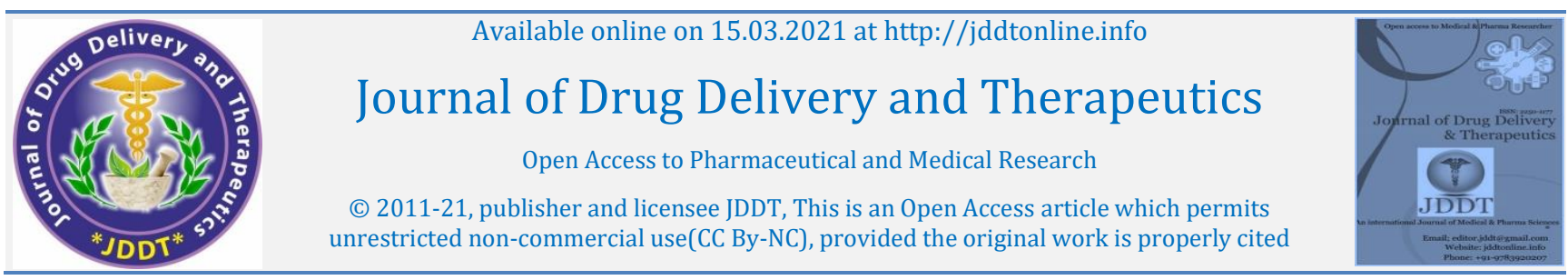

(C) 2011-21, publisher and licensee JDDT, This is an Open Access article which permits

Open Access Full Text Article

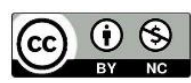

Research Article

\title{
Medicinal Plants Used to Heal Wound in Karandamalai of Dindigul District in Tamil Nadu, Southern India
}

\author{
Yasothkumar $\mathrm{N}^{*}$ \\ Department of Botany, Yadava College, Tiruppalai, Madurai - 625014, Tamil Nadu, India
}

Article Info:

$\begin{array}{ll} & \text { Article History: } \\ & \text { Received 13 Jan 2021; } \\ & \text { Accepted 04 March 2021; } \\ & \text { Available online 15 March } 2021\end{array}$

Cite this article as:

Yasothkumar N, Medicinal Plants Used to Heal Wound in Karandamalai of Dindigul District in Tamil Nadu, Southern India, Journal of Drug Delivery and Therapeutics. 2021; 11(2):72-75 DOI: http://dx.doi.org/10.22270/jddt.v11i2.4601

\author{
Abstract
}

Due to the presence of antibiotic or antiseptic nature's chemicals, plants are remarkable for the treatment of wounds. Having this fact as research theme, the present study was carried out to document the therapeutic uses of medicinal plants used to heal wound in Karandamalai of Dindigul district in Tamil Nadu. The frequent fieldwork was conducted from October 2019 to January 2020 for this study. The scientific name, family name, local name (in Tamil), part(s) used, mode of preparation, and mode of administration of medicine were recorded. A total of 24 medicinal remedies prepared from 24 plants were recorded. Further research on the phytochemistry and pharmacology of these medicinal plants should be conducted.

Keywords: Medicinal plants, Wound healing, Karandamalai, Dindigul district, Tamil Nadu.

\footnotetext{
*Address for Correspondence:

N. Yasothkumar, Associate Professor and Head, Department of Botany, Yadava College, Tiruppalai, Madurai 625014, Tamil Nadu, India.
}

\section{INTRODUCTION}

Medicinal plants can perform a significant role in the prevention of pathogenic attacks in the body. Plants are a great source of primary health care due to the presence of certain chemical compounds. They have been reported to be very beneficial in wound care, promoting the rate of wound healing with minimal pain, discomfort, and scarring to the patient ${ }^{1}$. Skin is the largest organ of the human body, as such plants showing dermatological properties and the ability to stop bleeding, and to heal wounds and burns are of great significance to human health 2 .

Research on the traditional knowledge related to plants used for wound healing still needs adequate attention. In this concern, the present study was carried out to document the therapeutic uses of medicinal plants existing in various locations of Karandamalai in Dindigul district of Tamil Nadu to heal wounds.

\section{MATERIALS AND METHODS}

2.1. Geographical profile of the study area Karandamalai

Karandamalai is one of the reserved forests located in Dindigul district of Tamil Nadu. It is situated south of Malaiyur and southeast of Chengaimedu. Geographically, Karandamalai is lies between $19.2849^{\circ} \mathrm{N}$ latitude and $78.2169^{\circ} \mathrm{E}$ longitude. The altitude of the study area ranged from 180 to $780 \mathrm{~m}$ above mean sea level. The temperature of the study area is about $13-38^{\circ} \mathrm{C}$ and annual rainfall reaches $105 \mathrm{~mm}$.

\subsection{Methodology}

Frequent field visits were made in different localities of Karandamalai from October 2019 to January 2020. Ethnomedicinal data on plants used to heal wounds were collected according to the methodology suggested by Jain ${ }^{3}$. The ethnomedcinal data (local name, mode of preparation, medicinal uses) were collected through questionnaire, interviews and discussions among the herbal practitioner in their local language. Totally 17 peoples were interviewed during this study and it includes 11 men and 6 women. The age of the informants was ranged from $34-62$. The plants were botanically identified by using regional floras 4,5 and authenticated as per APG IV classification ${ }^{6}$.

\section{RESULTS AND DISCUSSION}

\subsection{Wound healing medicinal plants}

A total of 24 medicinal plants used for the treatment of wounds were recorded by this present investigation. The 24 plant species were belongs to 18 families (Table 1). Asteraceae was found as dominant family with 3 species. It was followed by Asclepiadaceae, Euphorbiaceae, Fabaceae and Liliaceae ( 2 species each). The remaining 13 families were recorded with one species each (Table 2). According to the life form of the plants documented, herbs were found maximum (14 nos., 58.33\%) than trees (5 nos., 20.83\%), shrubs (3 nos., $12.50 \%$ ) and climbers (2 nos., 8.33\%) (Fig 1). 
Table 1: List of wound healing plants recorded in the study area

\begin{tabular}{|c|c|c|c|c|}
\hline Botanical name & Family & Local name & Habit & Medicinal uses \\
\hline Acalypha indica L. & Euphorbiaceae & Kuppaimeni & Herb & $\begin{array}{l}\text { Leaf is made into paste and applied } \\
\text { externally }\end{array}$ \\
\hline Aegle marmelos Corr. & Rutaceae & Vilvam & Tree & $\begin{array}{l}\text { Leaf is made into paste and applied } \\
\text { topically }\end{array}$ \\
\hline Aloe vera (L.) Burm.f. & Liliaceae & Sotrukatralai & Herb & Leaf gel is applied externally \\
\hline $\begin{array}{l}\text { Aponogeton natans (L.) Engl. \& K. } \\
\text { Krause. }\end{array}$ & Aponogetonaceae & Parakelangu & Herb & $\begin{array}{l}\text { Tuber is ground with water and the } \\
\text { paste is applied topically }\end{array}$ \\
\hline Aristolochia bracteata Retz. & Aristolochiaceae & Aduthinnapalai & Climber & $\begin{array}{l}\text { Whole plant is made into paste and } \\
\text { applied on affected area }\end{array}$ \\
\hline Bauhinia purpurea L. & Fabaceae & Mandari & Tree & $\begin{array}{l}\text { Dried stem bark powder is applied } \\
\text { along with coconut oil }\end{array}$ \\
\hline Calotropis procera (Alton). R. Br. & Asclepiadaceae & Vellaierruku & Shrub & $\begin{array}{l}\text { Leaf extract with gingelly oil is } \\
\text { applied on affected area }\end{array}$ \\
\hline Celosia argentea $\mathrm{L}$. & Amaranthaceae & Pannaikeerai & Herb & Leaf paste is applied externally \\
\hline Cleome viscosa $\mathrm{L}$. & Capparidaceae & Naikadugu & Herb & Leaf paste is externally applied \\
\hline Commelina benghalensis $\mathrm{L}$. & Commelinaceae & Kanomvazhai & Herb & Whole plant extract is used as wash \\
\hline Curculigo orchioides Gaertn. & Amaryllidaceae & Nilappanai & Herb & $\begin{array}{l}\text { Root is made into paste and applied } \\
\text { externally }\end{array}$ \\
\hline $\begin{array}{l}\text { Dipteracanthus prostrata (Poiret) } \\
\text { Nees. }\end{array}$ & Acanthaceae & Kiranthinayagam & Herb & $\begin{array}{l}\text { Whole plant paste is applied } \\
\text { externally }\end{array}$ \\
\hline Heliotropium indicum $\mathrm{L}$. & Boraginaceae & Thelkodukku & Herb & $\begin{array}{l}\text { Leaf is ground with flower of Cassia } \\
\text { alata and applied topically }\end{array}$ \\
\hline Jatropha gossypifolia $\mathrm{L}$. & Euphorbiaceae & KaruAthalai & Shrub & $\begin{array}{l}\text { Stem latex is used to cure mouth } \\
\text { wound }\end{array}$ \\
\hline Launaea sarmentosa Willd. & Asteraceae & Ezhuthanipudu & Herb & $\begin{array}{l}\text { Whole plant is made into paste } \\
\text { along with leaf of Jatropha } \\
\text { glandulifera and boiled with castor } \\
\text { oil and this oil was applied }\end{array}$ \\
\hline Lawsonia inermis L. & Lythraceae & Maruthantri & Tree & Leaf paste is applied \\
\hline Mollugo nudicaulis Lam. & Aizoaceae & Parpatakam & Herb & Whole plant paste is applied \\
\hline $\begin{array}{l}\text { Oxystelma esculentum (L.f.) R.Br. ex } \\
\text { Schultes }\end{array}$ & Asclepiadaceae & Oocipallai & Climber & $\begin{array}{l}\text { Leaf paste is applied externally on } \\
\text { the affected area }\end{array}$ \\
\hline Phyla nodiflora (Willd.) Link. & Verbenaceae & Poduthalai & Herb & Leaf paste is applied topically \\
\hline Pithecolobium dulce (Roxb.) Benth. & Cluciaceae & Kodukaipulli & Tree & Leaf paste is applied externally \\
\hline Prosopis juliflora (SW.) DC. & Fabaceae & Vanni & Tree & $\begin{array}{l}\text { Leaf paste with mustard oil, is } \\
\text { applied }\end{array}$ \\
\hline Tridax procumbens $\mathrm{L}$. & Asteraceae & Vettukayapundu & Herb & Leaf paste is applied externally \\
\hline Urginea indica (Roxb.) Kunth. & Liliaceae & KadduVankayam & Herb & $\begin{array}{l}\text { Bulb paste is mixed with neem oil } \\
\text { and applied }\end{array}$ \\
\hline Xanthium indicum Koenig. & Asteraceae & Marul & Shrub & $\begin{array}{l}\text { Leaf is roasted in castor oil and } \\
\text { made into paste. This paste is } \\
\text { applied externally }\end{array}$ \\
\hline
\end{tabular}


Table 2: Families with no. of species

\begin{tabular}{|l|l|}
\hline Family & No. of species \\
\hline Acanthaceae & 1 \\
\hline Aizoaceae & 1 \\
\hline Amaranthaceae & 1 \\
\hline Amaryllidaceae & 1 \\
\hline Aponogetonaceae & 1 \\
\hline Aristolochiaceae & 1 \\
\hline Asclepiadaceae & 2 \\
\hline Asteraceae & 3 \\
\hline Boraginaceae & 1 \\
\hline Capparidaceae & 1 \\
\hline Clusiaceae & 1 \\
\hline Commelinaceae & 1 \\
\hline Euphorbiaceae & 2 \\
\hline Fabaceae & 2 \\
\hline Liliaceae & 2 \\
\hline Lythraceae & 1 \\
\hline Rutaceae & 1 \\
\hline Verbenaceae & 1 \\
\hline
\end{tabular}

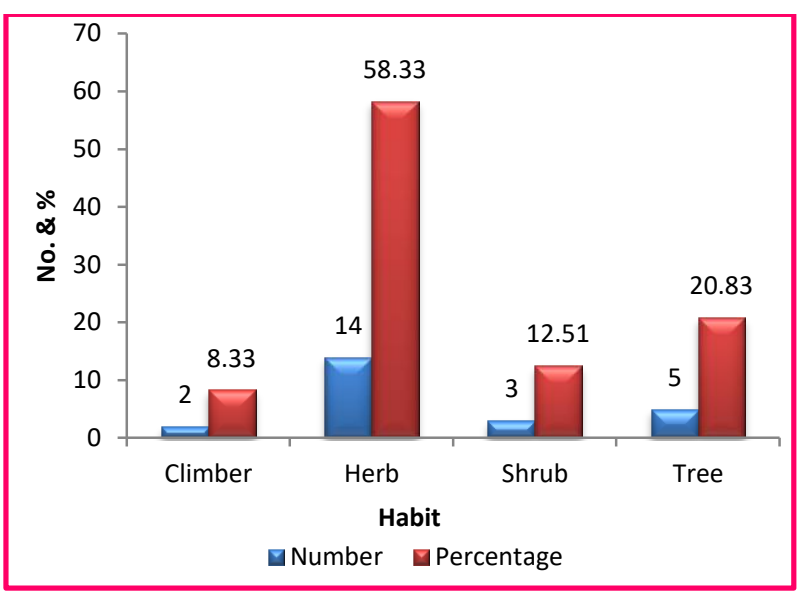

Figure 1: Number and Percentage of different habits

\subsection{Plant parts used}

The results of the present study also highlighted that leaves were used in 13 cases with $54.15 \%$ which was found as most preferable plant part used to cure wounds and whole plant was used in 5 cases $(20.83 \%)$. The following parts were used in only one case with low use percentage $(4.17 \%$ each): Bulb, Leaf gel, Root, Stem bark and Stem latex (Fig 2). Most of the earlier ethnobotanical studies conducted in various regions of Tamil Nadu confirmed that leaves are the preferable plant part used in the preparation of medicine 7 15.

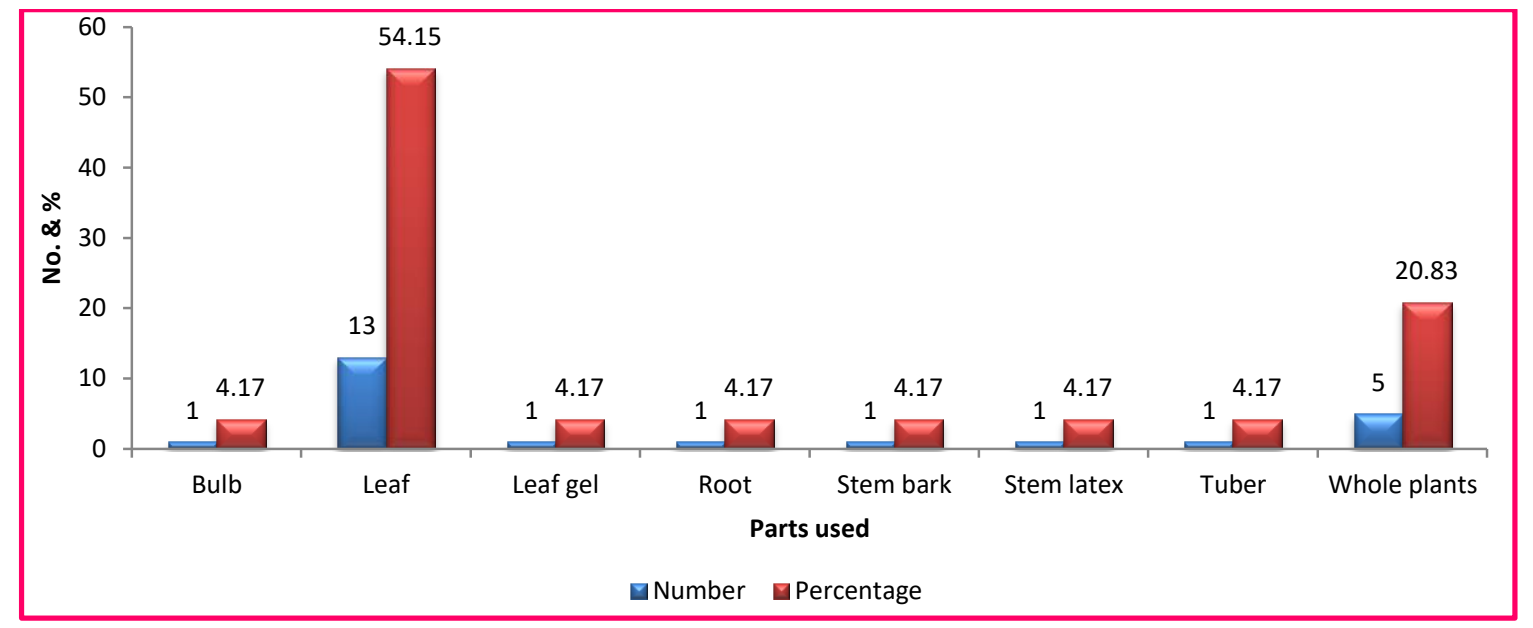

Figure 2: Number and Percentage of plant parts used

\subsection{Mode of medicinal preparation and application}

By this current research work, it was also found that the medicine were prepared mostly in the form of paste $(87.50 \%)$, followed by extract $(8.33 \%)$ and powder $(4.17 \%)$ (Fig 3). In case of administration of medicine, in 23 cases $(95.83 \%)$, it was applied topically and in one case $(4.17 \%)$ it was used as wash to heal the wound (Fig 4). These results were concordance with other ethnobotanical surveys conducted in other districts of Tamil Nadu, by which it was confirmed that the use of medicines as paste was mostly used in the treatment of skin diseases including wounds 16-18.

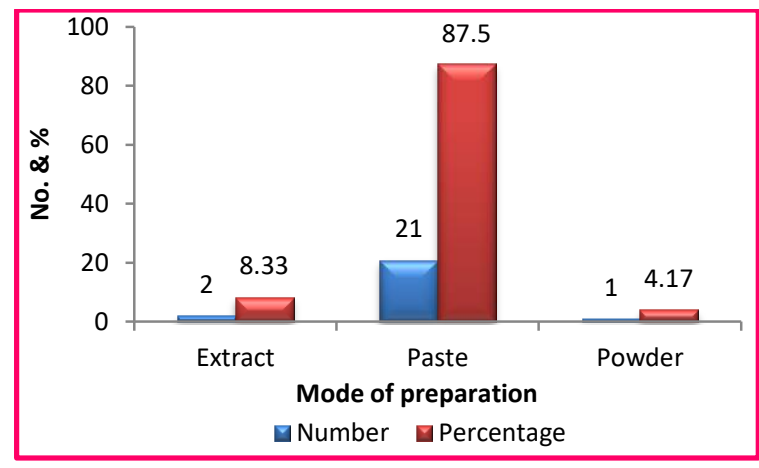

Figure 3: Number and Percentage of medicinal preparation 


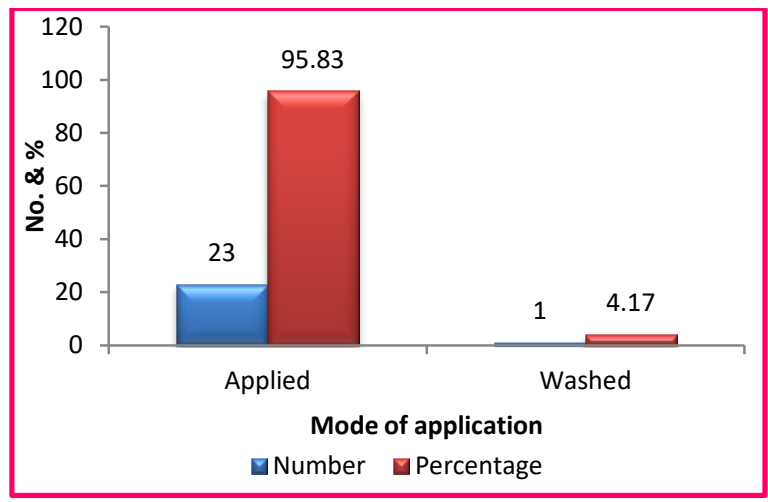

Figure 4: Number and Percentage of medicinal application

\section{CONCLUSION}

Phytochemical and pharmacological values of these plants should be tested and attention should also be made on proper exploitation and utilization of these plants; otherwise, there will be the possibility of extinction of particular species in the future.

\section{ACKNOWLEDGEMENT}

The author is cordially grateful to the informants of the study area for their valuable data.

\section{CONFLICT OF INTEREST}

The author has declared that there is no conflict of interest.

\section{REFERENCES}

1. Odimegwu DC, Ibezim EC, Esimone CO, Nworu CS \& Okoye FBC. Wound healing and antibacterial activities of the extract of Dissotis theifolia (Melastomataceae) stem formulated in a simple ointment base. Journal of Medicinal Plant Research, 2008; 2(1):011-016.

2. Lewis WH \& Elvin-Lewis MPF. Medical Botany: Plants affecting human health. John Wiley and Sons, New York, New York, 2003.

3. Jain SK. Method and Approaches in Ethnobotany. Society of Ethnobotanists, CDRI, Lucknow, 1989.

4. Gamble JS \& Fischer CEC. The Flora of the Presidency of Madras (Reprint Edited), Vols. I - III. Botanical survey of India, Calcutta, India, 1957.

5. Matthew KM. An Excursion Flora of Central Tamil Nadu. Oxford and IBH Publishing Co. Pvt. Ltd., New Delhi, India, 1991.

6. APG IV. An update of the Angiosperm Phylogeny Group classification for the orders and families of flowering plants. Botanical Journal of the Linnean Society, 2016; 181(1):1-20.
7. Shanmugam S, Rajagopal V \& Rajendran K. Multipurpose usable plants in Thalaiyanai hills of Tirunelveli forest division in southern part of Western Ghats. Journal of Non-Timber Forest Products, 2007; 14(4):297-306.

8. Shanmugam S, Ramar S, Ragavendhar K, Ramanathan R \& Rajendran K. Plants used as medicine by Paliyar tribes of Shenbagathope in Virudhunagar district of Tamil Nadu. Journal of Economic and Taxonomic Botany, 2008; 32(4):922-929.

9. Shanmugam S, Manikandan K \& Rajendran K. Ethnomedicinal survey of medicinal plants used for the treatment of diabetes and jaundice among the villagers of Sivagangai district, Tamil Nadu. Ethnobotanical Leaflets, 2009; 13:186-193.

10. Shanmugam S, Annadurai M \& Rajendran K. Ethnomedicinal plants used to cure diarrhea and dysentery in Pachalur hills of Dindigul district in Tamil Nadu, Southern India. Journal of Applied Pharmaceutical Sciences, 2011a; 1(8):94-97.

11. Shanmugam S, Kalaisevan M, Selvakumar $P$, Suresh K \& Rajendran K. Ethnomedicinal pants used to cure diarrhea and dysentery in Sivagangai district of Tami Nadu, India. International Journal of Research in Ayurveda and Pharmacy, 2011b; 2(3):991-994.

12. Shanmugam S, Rajendran K \& Suresh K. Traditional uses of medicinal plants among the rural people in Sivagangai district of Tamil Nadu, Southern India. Asian Pacific Journal of Tropical Biomedicine, 2012a; 2:S429-S434.

13. Shanmugam $S$, Balamurugan $S$, Pandiselvam $P$ \& Rajendran $K$. Medicinal plants used by the people of Thiruppuvanam and its surrounding areas of Sivagangai district in Tamil Nadu, Southern India. Journal of Basic and Applied Biology, 2012b; 6:39-45.

14. Shanmugam S, Jeyaprabakaran G \& Rajendran K. Medicinal trees from home gardens of urban areas in Madurai district of Tamil Nadu, Southern India. Asian Journal of Ethnobiology, 2020; 3(1):10-15.

15. Shanmugam S, Sundari A, Muneeswaran S, Vasanth C, Jayakumararaj R \& Rajendran K. Ethnobotanical Indices on medicinal plants used to treat poisonous bites in Thiruppuvanam region of Sivagangai district in Tamil Nadu, India. Journal of Drug Delivery and Therapeutics, 2020; 10(6s):31-36. DOI https://doi.org/10.22270/jddt.v10i6-s.4432

16. Chendurpandy P, Mohan VR \& Kalidass C. An ethnobotanical survey of medicinal plants used by the Kanikkar tribe of Kanyakumari district of Western Ghats, Tamil Nadu for the treatment of skin diseases. Journal of Herbal Medicine and Toxicology, 2020; 4(1):179-190.

17. Sundari A, Jayakumararaj R, Herbal remedies used to treat skin disorders in Arasankulam region of Thoothukudi District in Tamil Nadu, India. Journal of Drug Delivery and Therapeutics, 2020; 10(5):33-38.

DOI https://doi.org/10.22270/jddt.v10i5.4277

18. Sundari A \& Jayakumararaj R. Medicinal plants used to cure cuts and wounds in Athur region of Thoothukudi district in Tamil Nadu, India. Journal of Drug Delivery and Therapeutics, 2020; 10(6-s):26-30. DOI https://doi.org/10.22270/jddt.v10i6-s.4429 